\title{
Chapter 3 \\ Interpersonal Networks in Foreign \\ Assignments and Intercultural Learning \\ Processes
}

\author{
Erika Spieß
}

\section{Globalization and Foreign Assignment}

Due to the pressures of competition resulting from the globalization of markets, international experience has gained importance, and in fact become a vital asset (Carpenter, Sanders, \& Gregerson, 2001; Landy \& Conte, 2008). Multinational companies, in particular, regard foreign assignment experience as a market advantage (Spreitzer, McCall, \& Mahoney, 1997). For employees, international professional experience in this context has become a prime prerequisite for becoming an executive (Daily, Certo, \& Dalton, 2000).

This growing trend to send staff on foreign assignment is accompanied by a need to know what has to be done for expatriates to adjust successfully. Employees working in a foreign country are confronted with major changes in various areas, changes requiring their preparation prior to the foreign sojourn and support during it. If this does not occur, there is a risk that employees may feel stressed, be unable to work effectively, and, if worst comes to worst, have to end their sojourn prematurely.

The different phases of a foreign assignment (Kühlmann \& Stahl, 2001/2006) preparation, sojourn, and return-harbor certain risks. Due to time constraints, preparation is often inadequate or does not occur at all. The risks associated with the assignment are country-specific as well as of a private nature. Western expatriates in China experienced a "classic" culture shock (Selmer, 1999) and transferees uninterested in the country of assignment had difficulty adapting and, consequently, being effective for the company (Selmer, 2001). The larger the cultural distance to the country of origin the more difficult a foreign assignment may turn out to be (Wang, 2002). There is the danger of culture shock limiting an expatriate's ability to do

\footnotetext{
E. Spieß $(\varangle)$

Department Psychologie, Ludwig-Maximilians-Universität (LMU),

Leopoldstraße 13, 80802 Munich, Germany

e-mail: erika.spiess@psy.lmu.de
} 
his or her job. A lack of appreciation for returnees by company and home colleagues has been observed as a problem during the return phase (Kupka, Everett, \& Cathro, 2008; Szkudlarek, 2010).

To facilitate adjustment during the sojourn, some large corporations institute comprehensive mentoring programs embedded in personnel development measures and processes (Noe, Greenberger, \& Wang, 2002). Hechanova, Beehr, and Christiansen's (2003) meta-analysis described the antecedents and consequences of the adjustment of transferees on foreign assignment. Self-efficacy-the belief in one's ability to act, the frequency of interaction with people from the host country, interpersonal skills, and family support proved to be the main predictors for successful adjustment to the entire environment.

For instance, Wang and Kanungo (2004) demonstrated that the role of interpersonal networks is often neglected, although it has a direct and significant positive influence on the transferee's well-being. Caligiuri and Lazarova (2002) developed a model showing the relationship between social network, social support, and adjustment. They assumed that social interaction and social support (e.g., family members, coworkers in the country of sojourn, transferees from home and other countries) could help activate psychological resources with the capacity to intensify recognition and confirmation, attributes that in turn can substantially improve intercultural adjustment. Social support can act as a buffer against stress that usually occurs as the transferee tries to adjust to the new environment. Successful intercultural adjustment is closely related to network partners and social support.

In the following I present Kurt Lewin's field theory as a theoretical framework for my discussion of networks, social support in different fields of application, and personal initiative and for my examination of the relationship between social support and work adjustment. In conclusion results are considered regarding their specific meaning for the intercultural learning process and within the framework of field theory.

\section{Theoretical Framework}

Lewin's field theory is an important model for explaining economic action in significant fields of application. The central idea of Lewin's theory is that people are drawn to some things in their environment and repelled by others. In the Lewinian sense, all actors are situated in a field: They act, bring things into motion, influence others, launch campaigns, and are, for their part, exposed to various, even antagonistic behavioral forces. The advantage of the concept of field is its understanding that a person exists in a field of tensions, with the tensile and pressure forces within the field enabling a description of human behavior. In contrast to behaviorism's mechanistic image, field theory assumes that a person is active, perceiving and assessing his or her surroundings (Lewin, 1943, 1951/1963). Lewin (1939) regards the psychological environment functionally as "a part of one interdependent field, the life-space, the other part of which is the person" (p. 878). He expresses this in 
his famous formula: "Behavior $=$ Function of person and environment $=$ Function of life-space" (p. 878).

"Lewin's field theory states that it is possible to understand the basis for changing the behavior of individuals and groups by constructing a 'life space' comprising the psychological forces influencing their behavior at a given point in time" (Burnes \& Cooke, 2012a, p. 409). According to Burnes and Cooke (2012a), field theory played a central part in all of Lewin's work by allowing him to understand the forces that would need to be either strengthened or weakened in order to bring out desired behavior. Burnes and Cooke (2012a) reviewed and reevaluated field theory, arguing that the main reason for the decline of field theory was Lewin's pursuit of mathematical rigor over practical relevance. In psychology, field theory is closely associated with Gestalt psychology.

Six fundamental characteristics underpin Lewin's field theory (Burnes \& Cooke, 2012a, p. 411; Lewin, 1943):

1. Constructive method: The meaning of any concept is derived from its relationship to other concepts.

2. Dynamic approach: Lewin saw equilibrium in social life as a dynamic process where change occurs, but a recognizable form is maintained.

3. Psychological approach: The elements of an individual's or group's life space must be based on their perception of their reality at the time rather than seeking to construct it from the objective viewpoint of an observer.

4. Analysis beginning with the situation as a whole: All psychological events are conceived to be a function of the life space. One needs to consider the situation as a whole.

5. Behavior as a function of the field at the time it occurs: The focus is on the behavior of an individual in the "here and now." Behavior is not caused by something in the past or the future, but is grounded in the totality of the present situation.

6. Mathematical representations of the psychological situation: Lewin maintained that psychology had to represent behavior in mathematical terms.

Lewin saw field theory as a way of combining scientific rigor and practical relevance by offering a rigorous, theory-based method for analyzing behavior and as a practical approach to changing behavior by allowing individuals to understand their actions better. He saw behavior as the product of the environment and of the way in which individuals interpret external stimuli (Burnes \& Cooke, 2012a, p. 412). Five of the fundamental principles were derived from Gestalt psychology; the sixth principle was inspired by Cassirer's philosophy of science.

After Lewin's death in 1947, his work on group dynamics, action research, and his three-step model of change was taken up by other scholars and became the basis of organizational development (OD). His work on field theory went into decline until the 1990s, when it once again began to attract the attention of scholars and practitioners to behavioral and organizational change (Burnes \& Cooke, 2012a, p. 416). There is "a growing recognition of the relevance of Lewin's work to contemporary organizational concerns, especially change, ethics and values" (p. 418). 


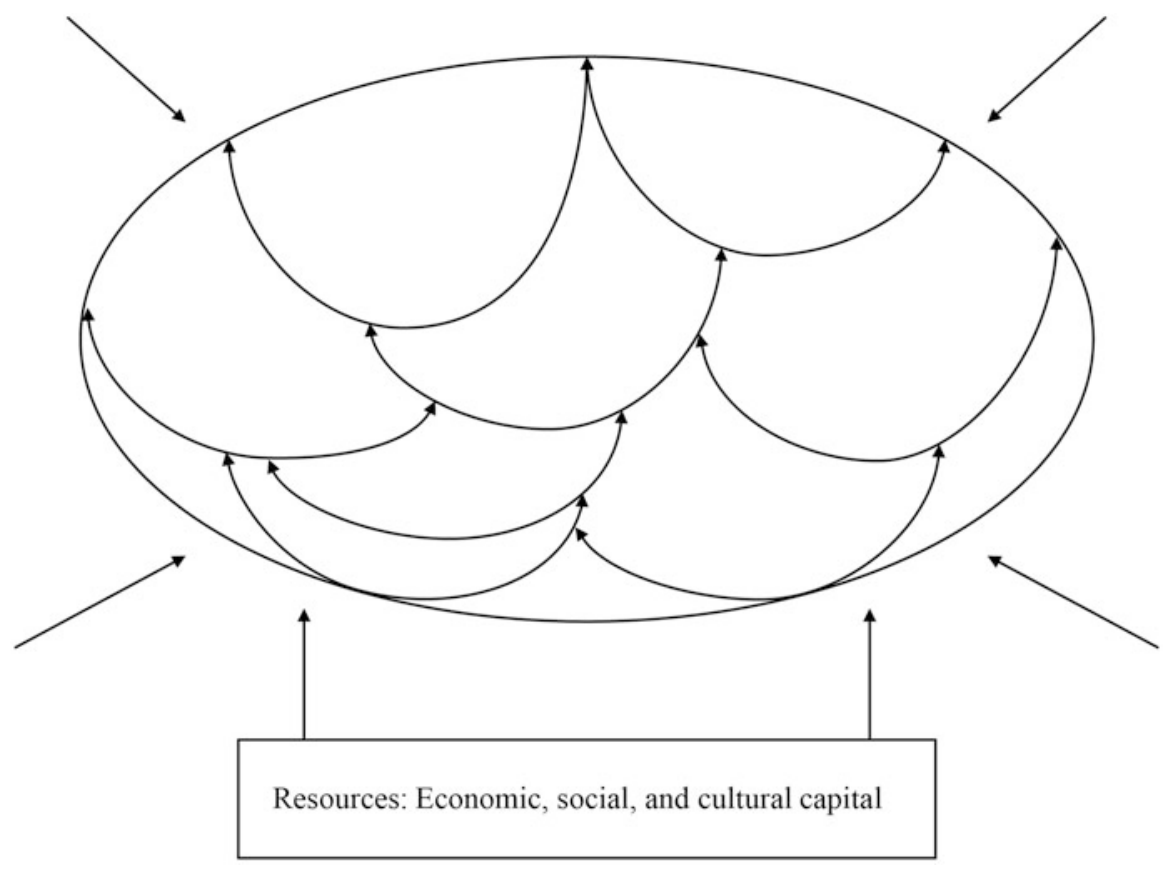

Fig. 3.1 Expanded metaphor of the field theory (Design by author)

Burnes and Cooke (2012b) asserted that the core components of OD have strong connections with the work of Kurt Lewin, summarizing that "Lewin's field theory was a significant break with the contemporary view of human behavior. It offered a holistic view of human behavior that focused on the entirety of a person or groups perceptual or psychological environment" (p. 420).

Bourdieu's (1983) sociocultural approach points out the different assumptions of active actors in an economic field. He differentiates between economic, cultural, and social capital. Economic capital comprises material resources such as income and money; social capital comprises relations and social networks; and cultural capital comprises resources such as cultivation, education, and lifestyle. Bourdieu stresses the specialness of cultural capital, whose transmission occurs within the family. Incorporating this cultural capital takes a lot of time (e.g., education). An economic field is distinguished by especially high dynamics, with the situation and individuals characterized by rapid change, competition, and quick action. Additional features are limited rationality and acting under great uncertainty. Typical in the Lewinian sense is the analysis of the interaction between the actors and the situation at hand. In Bourdieu's (1983) extension of field theory, the actors' social, cultural, and economic resources must also be considered. Figure 3.1 is simply an abstract metaphor for the forces interacting in an economic context (Spieß, 2006). 
Lewin's field theory provides a suitable framework, representing a metaphor and a model for the process-like course of psychoeconomic fields of topics. The inclusion of actors' assumptions - their economic, social, and cultural capital-in Lewin's field theory offers a more precise and differentiated view. Among the various applications of field theory, Elsass and Veiga (1994), for example, used field theory as a way to explain acculturation within organizations.

\section{The Role of Networks}

The concept of flexible, open organizations, which are willing to learn, continues to replace rationalistic and rule-oriented notions of appropriate behavior in organizations. In this regard, networks can be seen as structures that are more suitable than bureaucratic organizations.

A network is defined by the cooperative work of its participants, as well as by stability, voluntariness of participation, trust, individual objectives, and the objectives of the network partners, including autonomy and interdependency (Borgatti \& Foster, 2003). The ego-centered network is a distinct type of network, focused on an actor (ego), who then identifies the network partners (alteri). This is the conceptual basis for the coauthored studies by Stroppa and Spieß $(2010,2011)$ discussed in this chapter.

The participants in a network are influenced by group processes, which leads to network partners interacting primarily with people similar to themselves (regarding race, gender, and status). This produces fewer conflicts, but also results in less diversity (e.g., creativity in terms of product development). Networks have unique structural forms that offer certain advantages over those of hierarchies and markets (Powell, 1990). They are flexible and fast-working, offer favorable terms for learning processes and knowledge exchange, and reduce the level of uncertainty, which is particularly high for market-related transactions.

The development and sustainability of networks relies heavily on trust. Networks facilitate access to specific resources and information (Borgatti \& Foster, 2003). According to Sydow (1992), networks establish a link between organizational and interorganizational flexibility, with openness forming one of their core characteristics.

Making organizations more efficient by decentralizing and restructuring them reduces the existing division of labor, so an objective is to form networks of equal, self-regulating organizational entities. However, these networks can only work if decision-making processes and employee cooperation are successful (Cross, Kaše, Kilduff, \& King, 2013).

One functional characteristic of networks is social support, which offers network participants reliability and gives them backing. Social control, however, is also a functional network characteristic linked to social support-for example, in terms of norm orientation and the transmission of values. Networks can play an important role regarding foreign assignments. 


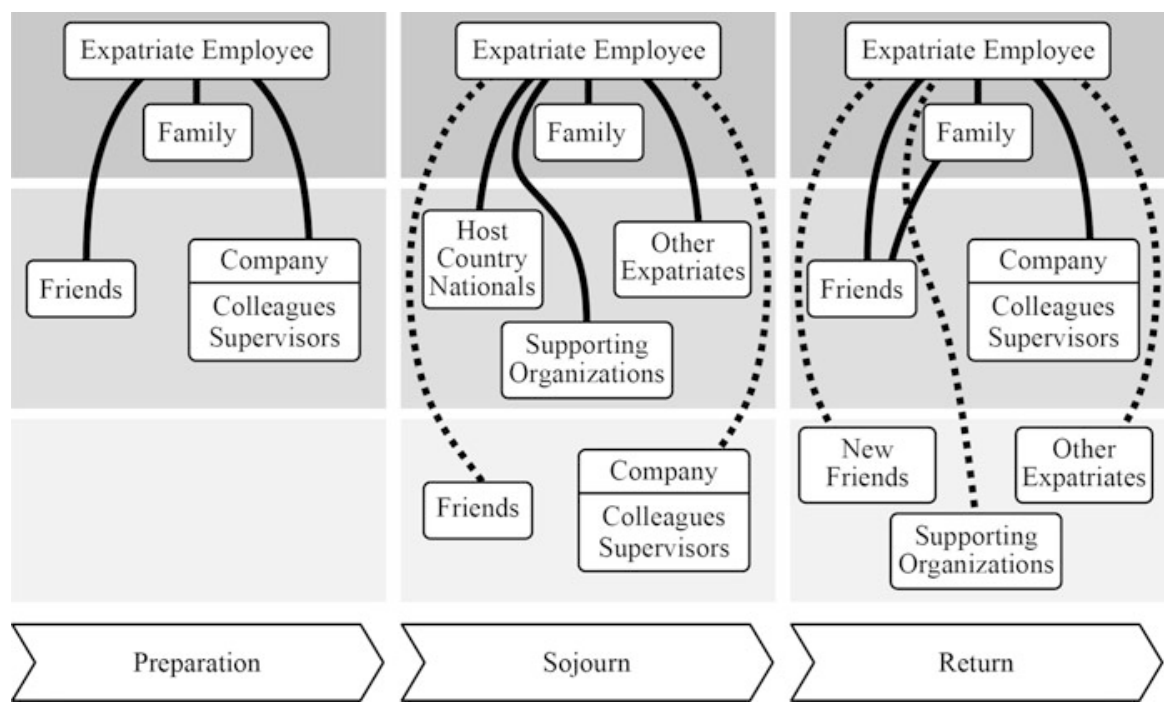

Fig. 3.2 The interpersonal networks during foreign assignment. Solid lines represent stronger relationships and dotted lines weaker ones. From Spieß (2009, p. 172) (Copyright 2009 by Oldenbourg. Reprinted by permission)

In a coauthored qualitative study focusing on interpersonal networks of expatriates (Spieß, Schaaf, \& Stroppa, 2009) I considered the network partners present during the different phases of the foreign assignment who form the social net and grant social support. The procedure and instruments of the qualitative study were guided interviews with expatriates of small and medium-sized companies from April to July 2006. Guidelines were developed for each of the phases of preparation, sojourn, and return. The participants were 16 respondents: male, between 27 and 47 years old, working in medium-sized companies in Munich and surroundings in the fields of electronics, conveyor systems, paper manufacturing, engineering, and mechanical engineering. Their destinations were China, Japan, Thailand, and Indonesia.

In the preparation phase of an assignment the network partners are different than those during the sojourn or return, including, for example, family, friends, colleagues, superiors, and the organization itself. During the sojourn the network expands to include contacts with host-country nationals, other expatriates, and the organizations that provide support to the expatriates - contacts that can then continue to exist as part of the network after the return. The interpersonal networks are further divided into sub-networks, with the respondents in the study viewing the professional network as separate from the private network. Family and friends form part of the private network, whereas colleagues, superiors, and the organization itself are part of the professional network.

Figure 3.2 illustrates interpersonal networks during foreign assignment. Results of the 2009 study showed that all respondents attached great value to their families. In the phase of sojourn a change could be noted. The expatriate employees lost 
contact with their old friends and colleagues, but formed contacts with other expatriates and host-country nationals, as well as receiving help from support organizations. When they returned, this constellation changed again and they lost contact with their new friends and other expatriates.

Respondents regarded family as highly important in every phase of the assignment, which is why the concept of family is located adjacent to the expatriate employee in Fig. 3.2. This does not imply that the family always stands by the expatriate's side. Rather, the figure refers to the ideational value of family as such, a perspective that is even more compelling when one is separated from the family. During the preparation phase family is followed in precedence by friends, colleagues, superiors, and the organization itself. Respondents also pointed out that keeping in contact with family members demanded additional effort during the sojourn. Contacts with friends, in particular, suffered due to the lack of time. This was reflected in statements such as "One can only work, eat, and sleep," or, if the expatriate was accompanied by a spouse, "Only a busy wife is a good wife, a bored wife is torture."

During the sojourn, this list expands to include new colleagues, other expatriates, and host-country nationals, as well as the supporting organizations. The relationship with friends from home becomes less important (indicated by the dotted lines in Fig. 3.2). In the phase of returning, the expatriates try to reestablish contact with the network partners from the preparation phase and to maintain relationships newly formed during the sojourn, but these, too, lose importance. It is, therefore, crucial to point out that there is hardly any networking activity between the network partners themselves. The connecting lines in Fig. 3.2 show relationships between the expatriate employee and various network partners, but only a single link among the network partners. In their review of organizational social network research, Kilduff and Brass (2010) emphasized its focus on relations between actors.

\section{The Role of Social Support}

In recent years, a number of research projects have focused on social support in various contexts, including family, friends, and work (e.g., Glazer, 2006; Stroebe \& Stroebe, 1998). The concept of social support is founded in various research traditions that also deal with the interrelationship of social support and mental health.

From the standpoint of a resource concept (Udris, 1997), social support is not only an external resource that a person receives but also an internal resource that an individual can develop (Udris \& Frese, 1999). Dücker (1995) describes various forms of support experienced by members of a network: material support (e.g., financial), support in the form of helping behavior (e.g., care in the case of illness), emotional support (e.g., affection, trust, or sympathy), feedback (e.g., social confirmation), informative support, orientation assistance (e.g., advice), and positive social activities (e.g., fun and recreation. 
Many studies (overview in Cohen \& Wills, 1985) have shown a positive influence of social support at work on the well-being of those receiving it. Frese and Semmer (1991) named further social support mechanisms. First, social support is a primary need expressing humans' phylogenetic urge to work in a social group. The lack of social support automatically leads to a diminution of well-being. And second, the positive feedback connected with social support directly affects selfconfidence and, thus, other components of mental well-being. Social support and the formation of networks are, therefore, closely related. The network concept is considered broad and multidimensional (Inkpen \& Tsang, 2005) and consequently suited as an umbrella concept for social support.

In the case of foreign assignment, various relationships within the interpersonal network of an expatriate are of interest, including those with the spouse, friends, and coworkers, mattering in both the home country and the country of sojourn. These networks may be considered an objective reality within which there are dyadic relationships of different strengths.

Social support is an essential component of our daily lives and takes on a special significance in the context of assignment to a foreign country. Adelman (1988) expressed it as follows: "Our ability to cope with daily stressors, critical life transitions and environmental or cultural change is inextricably tied to the social ecology in which we are embedded" (p. 183). The entire social network and the accompanying social support of family, friends, and coworkers are of eminent importance in eliminating the risk of failure of the foreign assignment.

The mentioned risks and the antecedents for successful adjustment have been primarily studied in large corporations (e.g., Mendenhall \& Oddou, 1985; Ward \& Rana-Deuba, 1999). The situation in small and medium-sized companies remains unclear, but it may be assumed that it is especially difficult, because small companies do not have the corresponding resources at their disposal. In this context, interpersonal networks for small and medium-sized company transferees on foreign assignment are gaining significance, although the involved company often underestimates their effect.

\section{Social Support and Firm Size}

A study published in "Expatriates' Social Networks: The Role of Company Size" by Stroppa and Spieß (2010) extended and tested Caligiuri and Lazarova's (2002) model for the influence of support provided by different network partners (supervisors, coworkers, friends, spouses) on received socioemotional and instrumental support. This model was extended by examining the impact of company size on effectiveness of support. Ninety expatriates were questioned during their foreign assignment: 45 from small and medium-sized enterprises (SMEs) and 45 from large companies. As expected expatriates who received support from their network partner coworkers during their foreign sojourn also received more instrumental support. In addition, the study confirmed that the type of company moderated the 
relationship between the network partner (friends) and socioemotional and instrumental support. The type of company had more influence on that support when there were no network partners (friends) available for the expatriates, and less when those contacts did exist. SMEs and their expatriate employees had less experience with environmental factors in different countries, less power to withstand the demands of host governments, and less reputation and financial resources, as well as fewer resources for managing international operations. In the future, therefore, it is very important that firms, especially SMEs, develop concepts for the effective support of staff on foreign assignment.

\section{Social Support and Host-Country Nationals}

Social support can be regarded as especially significant in the context of sojourners. Sources of support are wide ranging and can include many different social groups, such as family, friends, peers, coworkers, and supervisors.

A study published in "Social Support on International Assignments: The Relevance of Socioemotional Support From Locals" (Podsiadlowski, Vauclair, Spieß, \& Stroppa, 2013) identified the importance of support from host-country nationals. Using the matching or specificity hypothesis, which suggests that the right match between type and source of support is needed to increase well-being (Viswesvaran, Sanchez, \& Fisher, 1999, p. 318), the authors postulated that sojourners' satisfaction would increase if there were an optimal match between the type and source of social support (Madjar, 2008). One hundred thirty-one English-speaking participants living in New Zealand were sampled via a snowballing technique (Podsiadlowski et al., 2013). The results showed that both types of social supportinstrumental and socioemotional-were positively related to satisfaction with the sojourn, with socioemotional support being more important in predicting satisfaction with a sojourn than instrumental support, and support from host-country nationals being the most important source of social support. Furthermore, there was partial support for the matching specificity hypothesis. Only the amount of support from host-country nationals was a significant moderator and only the relationship between socioemotional support and satisfaction with a sojourn was moderated. The authors found only partial support for the matching or specificity hypothesis. The study's findings showed that it did not apply to instrumental support. Additionally, results showed that the right match between socioemotional support and source of support was more specific than expected. Only socioemotional support provided by hostcountry nationals increased satisfaction with the sojourn. Support from home did not moderate the relationship between socioemotional support and satisfaction. This indicates that only host-country nationals are able to provide relevant socioemotional support if individuals are faced with uncontrollable stressors.

To summarize, the most important predictors for satisfaction with a sojourn were support from host-country nationals and perceived socioemotional support. Not only did socioemotional support from host-country nationals have a positive effect, 
support received from other foreigners living in the respective country was not sufficient to assure a sojourner's well-being. Support from home was actually counterproductive for satisfaction with the sojourn. Findings (Podsiadlowski et al., 2013) emphasized the importance of receiving considerable socioemotional support from host-country nationals for a successful international assignment.

\section{The Role of Personal Initiative}

Personal Initiative is defined as a behavioral syndrome relating to individuals with an active, self-initiated approach to work that exceeds normal work behavior. Personal initiative is characterized by the following aspects (Frese, Kring, Soose, \& Zempel, 1996): it is consistent with the organization's mission, has long-term focus, is goal-directed and action-oriented, is persistent in the face of barriers and setbacks, and is self-starting and proactive. Social support and personal initiative have a strong relationship with successful work adjustment.

A study carried out by Stroppa and Spieß in 2011 adapted components of Fay and Frese's (2001) nomological network of personal initiative and Caligiuri and Lazarova's (2002) model for the influence of social support on adjustment. On this basis the authors developed and tested a model for the relationship between personal initiative, social support, and work adjustment. One hundred twenty-seven respondents answered an online questionnaire during and after their foreign sojourn. The study demonstrated that personal initiative moderates the relationship between social support from coworkers and job performance. Results showed that personal initiative of the expatriates and social support received from supervisors-but not from their coworkers - predicted job satisfaction, job stress, and job performance of the expatriates. The fact that personal initiative had a main effect on all three indicators of successful work adjustment indicates that it is a very important predictor for successful adjustment.

\section{Consequences for the Intercultural Learning Process}

Increasing internationalization demands intercultural action. From a psychological point of view, this interaction is special because it involves an overlapping situation. When meeting people of another culture one is in one's own culture as well as in another culture. The paradox is to adapt in a situation in which one becomes particularly aware of belonging to another culture (Lewin, 1963). This requires special preparation and training workshops.

The intercultural learning process can be described by the construct of intercultural sensitivity. Bennett's (1998) Developmental Model of Intercultural Sensitivity (DMIS) consists of three ethnocentric stages (denial, defense, minimization) and three ethnorelative stages (acceptance, adaptation, integration) constituting a contin- 
uum ranging from denial of difference to integration of difference. Denial of cultural difference is the state in which one's own culture is experienced as the only real one. Other cultures are either not perceived at all, or they are construed in rather vague ways. Defense against cultural difference is the state in which one's own culture is experienced as the only viable one. Minimization of cultural difference is the state in which elements of one's own cultural worldview are experienced as universal. Acceptance of cultural difference is the state in which one's own culture is experienced as just one of a number of equally complex worldviews. Adaptation to cultural difference is the state in which the experience of another culture yields perception and behavior appropriate to that culture. Integration of cultural difference is the state in which one's experience of self is expanded to include the movement in and out of different cultural worldviews (Hammer, Bennett, \& Wiseman, 2003, p. 424-425).

Hammer et al. (2003) summarized that, in general, the more ethnocentric orientations can be seen as ways of avoiding cultural difference, either by denying its existence, by raising defenses against it, or by minimizing its importance (p. 426). The more ethnorelative worldviews are ways of seeking cultural difference, either by accepting its importance, by adapting perspective to take it into account, or by integrating the whole concept into a definition of identity.

This theoretical framework provided conceptual guidance for Hammer et al. (2003) as they undertook the construction of the Intercultural Development Inventory (IDI) to measure the orientations toward cultural differences described in the DMIS. The result of this work is a 50-item, paper-and-pencil instrument (with 10 additional demographic items).

Referring to Lewin's field theory it is important to consider individual points of view and competencies as well as the social network, social support, cultural processes, and the current economic and political environment. The intercultural learning process, as well as intercultural sensitivity, is also important for foreign assignments and can help establish and connect networks more successfully. For this purpose, psychologists offer a measuring instrument, for example, the intercultural development inventory (Hammer et al., 2003). In addition to further intercultural learning and sensitivity, suitable trainings are also interesting and helpful.

The process of a foreign assignment can be viewed within the framework of Lewin's field theory, with the interaction between people and their environment clearly recognizable. According to the cited research (Stroppa \& Spieß, 2010, 2011; Podsiadlowski et al., 2013), a personal characteristic such as personal initiative is important, with it moderating the relationship between social support from coworkers and job performance. Environmental factors such as the size of the company also play a role.

Social support importantly involves a social interaction between the provider of support and the recipient, who can not only ask for support or aid, but also reject it. In the context of foreign assignments the support of superiors and colleagues and especially of host-country nationals (Podsiadlowski et al., 2013) has proven to be very important. Social support can also be seen as an aspect of networks, which can form connections within the field, possibly bringing together different strengths. I would therefore recommend a stronger coordination between the existing networks. 
My viewpoint also corresponds with Kilduff and Brass's (2010) observation that organizational social network research assumes dyadic relationships do not occur in isolation. However, the field of foreign assignments, which is marked by attracting and repelling forces, includes far more. Global development and climatic, economic, and cultural influences also have to be taken into consideration as highly relevant factors.

\section{References}

Adelman, M. B. (1988). Cross-cultural adjustment: A theoretical perspective on social support. International Journal of Intercultural Relations, 12, 183-204. doi:10.1016/01471767(88)90015-6

Bennett, M. J. (1998). Intercultural communication: A current perspective. In M. J. Bennett (Ed.), Basic concepts of intercultural communication: Selected readings (pp. 1-34). Yarmouth: Intercultural Press.

Borgatti, S. P., \& Foster, P. C. (2003). The network paradigm in organizational research: A review and typology. Journal of Management, 29, 991-1013. doi:10.1016/S0149-2063(03)00087-4

Bourdieu, P. (1983). The field of cultural production, or: The economic world reversed. Poetics, 12, 311-356. doi:10.1016/0304-422X(83)90012-8

Burnes, B., \& Cooke, B. (2012a). Kurt Lewin's field theory: A review and re-evaluation. International Journal of Management Reviews, 15, 408-425. doi:10.1111/j.14682370.2012.00348.x

Burnes, B., \& Cooke, B. (2012b). The past, present and future of organization development: Taking the long view. Human relations, 65, 1395-1429. doi:10.1177/0018726712450058

Caligiuri, P., \& Lazarova, M. (2002). A model for the influence of social interaction and social support on female expatriates' cross-cultural adjustment. International Journal of Human Resource Management, 13, 761-772. doi:10.1080/09585190210125903

Carpenter, M. A., Sanders, G., \& Gregerson, H. B. (2001). Bundling human capital with organizational context: The impact of international experience on multinational firm performance and CEO pay. Academy of Management Journal, 44, 493-511. doi:10.2307/3069366

Cohen, S., \& Wills, T. A. (1985). Stress, social support, and the buffering hypothesis. Psychological Bulletin, 98, 310-357. doi:10.1037//0033-2909.98.2.310

Cross, R., Kaše, R., Kilduff, M., \& King, Z. (2013). Bridging the gap between research and practice in organizational network analysis: A conversation between Rob Cross and Martin Kilduff [Special issue]. Human Resource Management, 52, 627-644. doi:10.1002/hrm.21545

Daily, C. M., Certo, S. T., \& Dalton, D. R. (2000). International experience in the executive suite: The path to prosperity? Strategic Management Journal, 21, 515-523. doi:10.1002/ (SICI) 1097-0266(200004)21:4<515::AID-SMJ92>3.0.CO;2-1

Dücker, B. (1995). Stress, Kontrolle und soziale Unterstützung im industriellen Bereich [Stress, control and social support in the industrial sector]. Bonn: Holos.

Elsass, P. M., \& Veiga, J. F. (1994). Acculturation in acquired organizations: A force-field perspective. Human Relations, 47, 431-453. doi:10.1177/001872679404700404

Fay, D., \& Frese, M. (2001). The concept of personal initiative: An overview of validity studies. Human Performance, 14, 97-124. doi:10.1207/S15327043HUP1401_06

Frese, M., Kring, W., Soose, A., \& Zempel, J. (1996). Personal initiative at work: Differences between East and West Germany. Academy of Management Journal, 39, 37-63. doi: $10.2307 / 256630$

Frese, M., \& Semmer, N. (1991). Stressfolgen in Abhängigkeit von Moderatorvariablen: Der Einfluß von Kontrolle und sozialer Unterstützung [Consequences of stress in dependence to moderator variables: The influence of control and social support]. In S. Greif, E. Bamberg, \& N. Semmer (Eds.), Psychischer Stress am Arbeitsplatz (pp. 135-153). Göttingen: Hogrefe. 
Glazer, S. (2006). Social support across cultures. International Journal of Intercultural Relations, 30, 605-622. doi:10.1016/j.ijintrel.2005.01.013

Hammer, M. R., Bennett, M. J., \& Wiseman, R. (2003). Measuring intercultural sensitivity: The intercultural development inventory. International Journal of Intercultural Relations, 27, 421443. doi:10.1016/S0147-1767(03)00032-4

Hechanova, R., Beehr, T. A., \& Christiansen, N. D. (2003). Antecedents and consequences of employees' adjustment to overseas assignment: A meta-analytic review. Applied Psychology, 52, 213-236. doi:10.1111/1464-0597.00132

Inkpen, A. C., \& Tsang, E. W. K. (2005). Social capital, networks, and knowledge transfer. Academy of Management Review, 30, 146-165. doi:10.5465/AMR.2005.15281445

Kilduff, M., \& Brass, D. J. (2010). Organizational social network research: Core ideas and key debates. Academy of Management Annals, 4, 317-357. doi:10.1080/19416520.2010.494827

Kühlmann, T. M., \& Stahl G. K. (2006). Problemfelder des internationalen Personaleinsatzes [Problem areas of international personnel placement]. In H. Schuler (Ed.), Lehrbuch der Personalpsychologie [Textbook of personnel psychology] (revised and expanded 2nd ed., pp. 533-558). Göttingen: Hogrefe. (Original work published 2001)

Kupka, B., Everett, A. M., \& Cathro, V. (2008). Home alone and often unprepared: Intercultural communication training for expatriated partners in German MNCs. International Journal of Human Resource Management, 19, 1765-1791. doi:10.1080/09585190802323819

Landy, F. J., \& Conte, J. M. (2008). Work in the 21th century: An introduction to industrial and organizational psychology. Personnel Psychology, 61, 447-450. doi:10.1111/j.17446570.2008.00119_2.x

Lewin, K. (1939). Field theory and experiment in social psychology: Concepts and methods. American Journal of Sociology, 44, 868-896. doi:10.1086/218177

Lewin, K. (1943). Defining the "field at a given time". Psychological Review, 50, 292-310. doi: $10.1037 / \mathrm{h} 0062738$

Lewin, K. (1963). Feldtheorie in den Sozialwissenschaften: Ausgewählte theoretische Schriften [Field theory in social science: Selected theoretical papers] (A. Lang \& W. Lohr, Trans.). Bern: Hans Huber. (Original work published 1951)

Madjar, N. (2008). Emotional and informational support from different sources and employee creativity. Journal of Occupational and Organizational Psychology, 81, 83-100. doi:10.1348/ $096317907 X 202464$

Mendenhall, M., \& Oddou, G. (1985). The dimensions of expatriate acculturation: A review. Academy of Management Review, 10, 39-47. doi:10.2307/258210

Noe, R. A., Greenberger, D. B., \& Wang, S. (2002). Mentoring: What we know and where we might go. Research in Personnel and Human Resources Management, 21, 129-174. doi:10.1016/S0742-7301(02)21003-8

Podsiadlowski, A., Vauclair, C.-M., Spieß, E., \& Stroppa, C. (2013). Social support on international assignments: The relevance of socioemotional support from locals. International Journal of Psychology, 48, 563-573. doi:10.1080/00207594.2012.669042.

Powell, W. W. (1990). Neither market nor hierarchy: Network forms of organizations. Research in Organizational Behavior, 12, 295-336. Retrieved from http://woodypowell.com/wp-content/ uploads/2012/03/10_powell_neither.pdf

Selmer, J. (1999). Culture shock in China? Adjustment pattern of western expatriate business managers. International Business Review, 8, 515-534. doi:10.1016/S0969-5931(99)00018-9

Selmer, J. (2001). Psychological barriers to adjustment and how they affect coping strategies: Western business expatriates in china. International Journal of Human Resource Management, 12, 151-165. doi:10.1080/09585190010014106

Spieß, E. (2006). Lewin's contribution to economic psychology. In J. Trempala, A. Pepitone \& B. H. Raven (Eds.), Lewinian Psychology-Proceedings of the international conference: Kurt Lewin: Contribution to contemporary psychology (pp. 208-218). Bydgoszcz: Wielki University Press.

Spieß, E., Schaaf, E., \& Stroppa, C. (2009). Netzwerke sozialer Unterstützung bei Auslandsentsendungen nach Asien [Networks of social support during foreign assignments in 
Asia]. In T. Kühlmann \& H. D. Haas (Eds.), Internationales RisikomanagementAuslandserfolg durch grenzüberschreitende Netzwerke. [International risk management-success in foreign assignments through crossbordering networks] (pp. 155-183). Munich: Oldenbourg. doi:10.1524/9783486592719

Spreitzer, G. M., McCall, M. W., \& Mahoney, J. D. (1997). Early identification of international executive potential. Journal of Applied Psychology, 82, 6-29. doi:10.1037/0021-9010.82.1.6

Stroebe, W., \& Stroebe, M. (1998). Lehrbuch der Gesundheitspsychologie: Ein sozialpsychologischer Ansatz [Textbook of health psychology: A social psychological approach]. Frankfurt: Dietmar Klotz.

Stroppa, C., \& Spieß, E. (2010). Expatriates social networks: The role of company size. The International Journal of Human Resource Management, 21, 2306-2322. doi:10.1080/0958519 2.2010 .516586

Stroppa, C., \& Spieß, E. (2011). International assignments: The role of social support and personal initiative. International Journal of Intercultural Relations, 34, 234-245. doi:10.1016/j. ijintrel.2010.09.008

Szkudlarek, B. (2010). Reentry-A review of the literature. International Journal of Intercultural Relations, 34, 1-21. doi:10.1016/j.ijintrel.2009.06.006

Sydow, J. (1992). Strategische Netzwerke: Evolution und Organisation [Strategic networks: Evolution and organisation]. Wiesbaden: Gabler. doi:10.1007/978-3-322-86619-6

Udris, I. (1997). Soziale Unterstützung [Social support]. In S. Greif, H. Holling, \& N. Nicholson (Eds.), Arbeits- und Organisationspsychologie. Internationales Handbuch in Schlüsselbegriffen (pp. 421-425) [Work and organizational psychology. The international handbook of key terms]. (3rd ed.). Weinheim: Psychologie Verlags Union.

Udris, I., \& Frese, M. (1999). Belastung und Beanspruchung [Stress and strain]. In C. Graf Hoyos \& D. Frey (Eds.), Arbeits- und Organisationspsychologie. Ein Lehrbuch (pp. 429-445) [Work and organizational psychology. A textbook]. Weinheim: Beltz-PVU.

Viswesvaran, C., Sanchez, J. I., \& Fisher, J. (1999). The role of social support in the process of work stress: A meta-analysis. Journal of Vocational Behavior, 54, 314-334. doi:10.1006/ jvbe.1998.1661

Wang, X. (2002). Expatriate adjustment from a social network perspective: Theoretical examination and a conceptual model. International Journal of Cross-Cultural Management, 2, 321337. doi: $10.1177 / 147059580223003$

Wang, X., \& Kanungo, R. N. (2004). Nationality, social network and psychological well-being: Expatriates in China. The International Journal of Human Resource Management, 15, 775793. doi:10.1080/0958519042000192942

Ward, C., \& Rana-Deuba, A. (1999). Acculturation and adaptation revisited. Journal of CrossCultural Psychology, 30, 422-442. doi:10.1177/0022022199030004003

Open Access This chapter is distributed under the terms of the Creative Commons Attribution 4.0 International License (http://creativecommons.org/licenses/by/4.0/), which permits use, duplication, adaptation, distribution and reproduction in any medium or format, as long as you give appropriate credit to the original author(s) and the source, provide a link to the Creative Commons license and indicate if changes were made.

The images or other third party material in this chapter are included in the work's Creative Commons license, unless indicated otherwise in the credit line; if such material is not included in the work's Creative Commons license and the respective action is not permitted by statutory regulation, users will need to obtain permission from the license holder to duplicate, adapt or reproduce the material.

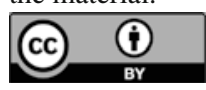

